\title{
Peran Orang Tua dalam Mengedukasi Anak untuk Mencuci Tangan sebagai Upaya Pencegahan Covid-19 di Desa Lingsar Wilayah Kerja Puskesmas Lingsar
}

\author{
Indah Wasliah ${ }^{1{ }^{*}}$, Heny Marlina Riskawaty ${ }^{1)}$, Elsa Karuniati ${ }^{1)}$, Syamdarniati ${ }^{1}$ ) \\ Email: indahwasliah80@gmail.com \\ 1) STIKES YARSI MATARAM
}

\begin{abstract}
ABSTRAK
Coronavirus Disease 2019 (COVID-19) adalah penyakit jenis baru yang belum pernah di identifikasi sebelumnya pada manusia. Data WHO menunjukkan jumlah angka Covid-19 di dunia sampai dengan tanggal 1 Desember 2020, dilaporkan total kasus konfirmasi 63.584.430. Sedangkan di Indonesia melaporkan kasus konfirmasi Covid-19 sebanyak 543.975 terkonfirmasi. Tujuan penelitian ini adalah untuk mengetahui bagaimana peran orang tua dalam mengedukasi anak untuk mencuci tangan sebagai upaya pencegahan Covid-19. Metode penelitian dan jenis penelitian ini yaitu penelitian kuantitatif dengan deskriptif analitik dengan metode cross-sectional. Jumlah sampel sebanyak 144 responden. Pengambilan sampel dilakukan dengan nonprobability sampling menggunakan tehnik purposive sampling dan penentuaan besar sampling dilakukan dengan menggunakan rumus Slovin. Pengumpulan data dilakukan menggunakan kuesioner yang sudah dilakukan uji validitas dan reabilitas. Data dianalisis dalam bentuk tabel distribusi frekuensi dalam bentuk persentase dengan hasil penelitian ini menunjukan peran orang tua dengan kategori berperan aktif sebanyak 139 orang $(96,5 \%)$, sedangkan untuk yang berperan kurang aktif sebanyak 5 orang $(3,5 \%)$. Berdasarkan hasil penelitian ini, didapatkan hampir seluruh orang tua sudah berperan aktif dalam menjelaskan dan membimbing anak dalam mencuci tangan sebagai upaya pencegahan Covid-19. Harapannya kepada para orang tua untuk selalu mengingatkan dan membimbing anak untuk mencuci tangan setelah beraktivitas di luar rumah maupun di dalam rumah, serta menyediakan fasilitas untuk mencuci tangan.
\end{abstract}

Kata kunci: Covid-19, Peran Orang Tua, Mencuci Tangan

\begin{abstract}
Corona Virus Disease 2019 (COVID-19) is a new type of disease that never been previously identified in humans. WHO data shows the number of Covid-19 in the world until December 1, 2020, reported with 63,584,430 confirmed of accumulation cases. Meanwhile, Indonesia reported 543,975 confirmed cases of Covid-19. Objective: The objective of the research was to find out role of parents in educating children to washing their hands as an effort to prevent Covid-19. Research Method: The type of research used in this research is quantitative research with analytical descriptive cross-sectional method. The numbers of samples in were 144 respondents.samplin was carried out bay non-probability sampling using purposive sampling technique and the determination of the sampling size was carried out using the Slovin formula. Data was collected using a questionnaire that has been tested for validity and reliability. The data were analyzed using frequency distribution table in the form of percentages. Results: The results of this research showed that the role of parents was mostly 139 people (96.5\%), while for those who played inactive roles were 5 people (3.5\%). Conclusion: Based on the result of this study, it was found that almost all parents have played an active role in explaining and guiding children in washing their hands as an effort to prevent Covid-19. Suggestion: Parents should always remind and guide their children to wash their hands after doing activities outside and inside the house, as well as providing facilities for washing hands.
\end{abstract}

Keywords: Covid-19, Role of Parents, Washing Hands 


\section{A. LATAR BELAKANG}

Indonesia sampai saat ini masih digemparkan dengan bencana non alam yang menimpa seluruh negara di dunia, bencana ini dikenal dengan Corona Virus Disease-19 (COVID-19). Coronavirus adalah keluarga besar virus yang menyebabkan penyakit mulai dari gejala ringan sampai berat. Coronavirus Disease 2019 (COVID-19) adalah penyakit jenis baru yang belum pernah di identifikasi sebelumnya pada manusia. Virus penyebab Covid-19 ini dinamakan Sars-CoV-2.

Tanda dan gejala umum infeksi Covid-19 antara lain gejala gangguan pernapasan akut seperti demam, batuk dan sesak napas. Masa inkubasi rata-rata 5-6 hari dengan masa inkubasi terpanjang 14 hari [1]. Pada kasus Covid-19 yang berat dapat menyebabkan pneumonia, sindrom pernapasan akut, gagal ginjal, dan bahkan kematian [2]. Tanda-tanda dan gejala klinis yang dilaporkan pada sebagian besar kasus adalah demam, dengan beberapa kasus mengalami kesulitan bernapas, dan hasil rontgen menunjukkan infiltrat pneumonia luas di kedua paru [3]. Pada 31 Desember 2019, WHO China Country Office melaporkan kasus pneumonia yang tidak diketahui etiologinya di Kota Wuhan, Provinsi Hubei, Cina. Pada tanggal 7 Januari 2020, Cina mengidentifikasi pneumonia yang tidak diketahui etiologinya tersebut sebagai jenis baru coronavirus (coronavirus disease, Covid-19). Pada tanggal 30 Januari 2020 WHO telah menetapkan sebagai Kedaruratan Kesehatan Masyarakat Yang Meresahkan Dunia/Public Health Emergency of International Concern (KKMMD/PHEIC) [4].

Penambahan jumlah kasus Covid-19 berlangsung cukup cepat dan sudah terjadi penyebaran antarnegara. Sampai dengan tanggal 1 Desember 2020, dilaporkan total kasus konfirmasi 63.584 .430 dengan 1.473 .738 kematian, 43.979.423 kesembuhan, dimana kasus dilaporkan di 220 negara/wilayah [5]. Di antara kasus tersebut, sudah ada beberapa petugas kesehatan yang dilaporkan terinfeksi.
Pada tanggal 1 Desember 2020, Indonesia melaporkan kasus konfirmasi Covid-19 sebanyak 543.975 terkonfirmasi, 454.879 sembuh, dan 17.081 meninggal [6].

Pemerintah secara resmi menetapkan Covid-19 sebagai Bencana Nasional melalui Keputusan Presiden Nomor 12 Tahun 2020 Penetapan Bencana Nonalam Penyebaran Covid-19 Sebagai Bencana Nasional. Perkembangan kasus Covid-19 di provinsi NTB pada tanggal 1 Desember 2020, diketahui 4.744 terkonfirmasi, 3.883 sembuh, 610 dirawat, dan 251 meninggal. Sedangkan untuk data Covid-19 di Kabupaten Lombok Barat, tanggal 1 Desember 2020 sebanyak 735 terkonfirmasi, 50 meninggal, 670 sembuh [7]. Untuk kasus Covid-19 di wilayah kerja Puskesmas Lingsar mulai terkonfirmasi sekitar bulan Maret, bedasarkan data terakhir dari Puskesmas Lingsat tanggal 22 Oktober 2020, diketahui 31 positif, 27 sembuh, dan 4 meninggal dunia yang tersebar di 8 desa wilayah kerja Puskesmas Lingsar. Dari data kasus positif tersebut, dinyatakan semua pasien telah sembuh [8].

Dikutip dari Kompas, tanggal 1 Desember 2020, Indonesia menjadi salah satu penyumbang kasus Covid-19 pada anak tertinggi di Asia. Kasus pada anak yang terinfeksi Covid-19 per 10 agustus 2020 telah mencapai 3.928 dan 59 anak yang meninggal, ini merupa kasus tertinggi di Asia. Data pada anak usia 0-5 yang positif Covid-19 sebanyak 2,5\% anak, dan untuk anak yang usia 6-18 tahun sebanyak 7,6\%. Pada tanggal 8 Desember 2020, hari Rabu 27 Mei 2020, Kepala Dinas Kesehatan NTB menyatakan ada 86 anak yang dinyatakan positif terinfeksi Covid-19 di NTB hingga Kamis, 28 Mei 2020. Dari 86 anak yang positif, 35 diantaranya balita rentan usia $0-5$ tahun $(5 \%)$ dan 51 anak rentan usia 5-18 tahun (10\%) [7].

Peran orang tua sangat diperlukan pada anak yang masih berada di usia sekolah, dimana peran ini bertujuan untuk membimbing dan memberikan penjelasan kepada anak agar dapat menentukan sesuatu hal yang benar atau salah untuk dilakukan [9]. Masalah yang sering 
muncul pada anak usia sekolah yaitu, kebiasaan tidak mencuci tangan setelah melakukan aktivitas baik itu bermain atau hal yang lain [10]. Orang tua merupakan pendamping anak pada saat melakukan aktivitasnya setiap hari, terutama dalam hal pendampingan mencuci tangan sebagai upaya pencegahan agar terhindar dari penularan Covid-19 [11]. Anak memerlukan orang tua untuk mendampinginya dalam upaya melindungi diri dari Covid-19 dengan menerapkan cuci tangan selama 20 detik menggunakan sabun dan air mengalir, menjaga jarak, dan menggunakan masker [12].

\section{B. METODE PENELITIAN}

Jenis penelitian yang digunakan yaitu penelitian kuantitatif jenis deskriptif analitik, menggunakan metode cross-sectional, dengan instrumen penelitian menggunakan kuesioner dan indikator penilaiannya yaitu mengetahui peran orang tua dalam mengedukasi anak untuk mencuci tangan sebagai upaya pencegahan COVID-19 di Desa Lingsar.

\section{HASIL DAN PEMBAHASAN}

Berdasarkan tabel 1.1 didapatkan hasil bahwa karakteristik umur orangtua yang mepunyai anak usia sekolah di desa Lingsar terbanyak yaitu dari usia 26-45 tahun sebanyak 122 orang $(84,7 \%)$.

Tabel 1.1 Distribusi Frekuensi Berdasarkan Umur Orang Tua di Desa Lingsar Wilayah Kerja Puskesmas Lingsar 2021

\begin{tabular}{ccc}
\hline Usia & $\mathbf{N}$ & $\mathbf{\%}$ \\
\hline $20-25$ & 2 & 1,4 \\
$26-45$ & 122 & 84,7 \\
$>45$ & 20 & 13,9 \\
\hline Jumlah & 144 & $100 \%$ \\
\hline
\end{tabular}

Tabel 1.2 Distribusi Karakteristik Berdasarkan Jenis Kelamin Orang Tua di Desa Lingsar Wilayah Kerja Puskesmas Lingsar 2021

\begin{tabular}{ccc}
\hline Jenis kelamin & $\mathbf{N}$ & $\mathbf{\%}$ \\
\hline Laki-laki & 6 & 4,2 \\
Perempuan & 138 & 95,8 \\
\hline Jumlah & 144 & $100 \%$ \\
\hline
\end{tabular}

Berdasarkan tabel 1.2 didapatkan hasil bahwa karakteristik jenis kelamin orang tua yang mepunyai anak usia sekolah di desa Lingsar terbanyak yaitu perempuan sebanyak 138 orang $(95,8 \%)$.

Tabel 1.3 Distribusi Frekuensi Responden Berdasarkan Jenis Pendidikan Orang Tua di Desa Lingsar Wilayah Kerja Puskesmas Lingsar 2021

\begin{tabular}{ccc}
\hline Jenis Pendidikan & $\mathbf{N}$ & $\mathbf{\%}$ \\
\hline SD & 65 & 45,1 \\
SMP & 15 & 10,4 \\
SMA & 50 & 34,7 \\
S1 & 14 & 9,7 \\
\hline Jumlah & 144 & $100 \%$ \\
\hline
\end{tabular}

Berdasarkan tabel 1.3 didapatkan hasil bahwa karakteristik pendidikan orang tua yang mepunyai anak usia sekolah di desa Lingsar terbanyak yaitu SD sebanyak 65 orang $(45,1 \%)$.

Tabel 1.4 Distribusi Frekuensi Responden Berdasarkan Jenis Pekerjaan Orang Tua di Desa Lingsar Wilayah Kerja Puskesmas Lingsar 2021

\begin{tabular}{ccc}
\hline Jenis Pekerjaan & N & \% \\
\hline IRT & 99 & 68,8 \\
Buruh & 6 & 4,2 \\
Pedagang & 20 & 13,9 \\
Honorer & 6 & 4,2 \\
Guru & 2 & 1,4 \\
Peternak & 1 & 0,7 \\
Wiraswasta & 5 & 3,5 \\
PNS & 5 & 3,5 \\
\hline Jumlah & 144 & $100 \%$ \\
\hline
\end{tabular}

Berdasarkan tabel 1.4 didapatkan hasil bahwa karakteristik pekerjaan orang tua yang mepunyai anak usia sekolah di desa Lingsar terbanyak yaitu ibu rumah tangga (IRT) sebanyak 99 orang $(68,8 \%)$, dan yang terendah adalah peternak sebanyak 1 orang $(0,7 \%)$. 
Tabel 1.5 Distribusi Frekuensi Pengetahuan Orang dalam Mengedukasi Anak untuk Mencuci Tangan di Desa Lingsar Wilayah Kerja Puskesmas Lingsar 2021.

\begin{tabular}{lcc}
\hline Pengetahuan & $\mathbf{N}$ & $\mathbf{\%}$ \\
\hline Aktif & 139 & 96,5 \\
Kurang aktif & 5 & 3,5 \\
\hline Jumlah & 144 & $100 \%$ \\
\hline
\end{tabular}

Berdasarkan tabel 1.5 didapatkan hasil bahwa karakteristik peran orang tua dengan kategori berperan aktif sebanyak 139 orang $(96,5 \%)$, sedangkan untuk yang berperan kurang aktif sebanyak 5 orang $(3,5 \%)$.

\section{Pencegahan Covid-19}

2019-nCoV adalah virus corona yang mengalami mutasi antigenik. Masa inkubasi virus adalah sesingkatnya 1 hari tetapi umumnya dianggap tidak lebih dari 14 hari. Tetapi perlu dicatat bahwa beberapa kasus yang dilaporkan memiliki masa inkubasi hingga 24 hari [13].

Cuci tangan merupakan langkah/upaya dalam memutus rantai penyebaran Covid-19, cuci tangan sesering mungkin dengan sabun dan air mengalir dapat menghilangkan kotoran serta membunuh bakteri maupun virus penyebab penyakit [14]. Cuci tangan segera setelah memegang benda, berjabat tangan atau setelah kontak dengan sekret pernapasan (misalnya setelah bersin).

Hal ini sesuai dengan penelitian Moh. Rivai Naoke (2020) bahwa mencuci tangan dengan air dan sabun tingkat keampuhan menghilangkan bakteri ditangan dapat berbeda, dalam hal ini jika hanya mencuci tangan dengan air, bakteri yang akan keluar hanya sedikit, sedangkan sabun dapat mengeluarkan banyak bakteri karena dalam sabun terdapat bahan khusus yang dapat mengendalikan bakteri yang ada pada tangan, dalam hal ini terdapat beberapa bahan aktif yang terkandung dalam sabun cuci tangan yaitu alkohol, emollient, triclocarban, triclosan, triclocorban, dan lainnya [15].

\section{Peran Orang Tua dalam Mengedukasi Anak Mencuci Tangan}

Berdasarkan hasil penelitian ini karakteristik umur orangtua yang mempunyai anak usia sekolah terbanyak yaitu dari usia 2645 tahun sebanyak 122 orang $(84,7 \%)$. Jenis kelamin terbanyak yaitu perempuan sebanyak 138 orang $(95,8)$. Pendidikan responden terbanyak yaitu SD sebanyak 65 orang $(45,1 \%)$. Pekerjaan responden terbanyak yaitu ibu rumah tangga (IRT) sebanyak 99 orang $(68,8 \%)$. Peran orang tua terbanyak yaitu dengan kategori berperan aktif sebanyak 139 orang (96,5\%), sedangkan untuk yang berperan kurang aktif sebanyak 5 orang $(3,5 \%)$.

Peran orang tua yang memunyai anak usia sekolah yang didapatkan di lapangan dipengaruhi oleh faktor kelamin, pendidikan, dan pekerjaan. Bedasarkan karakteristik jenis kelamin peran orang tua terbanyak yaitu perempuan, hal ini dipengaruhi karena orang tua yang lebih berperan dalam mendidik anak di rumah yaitu ibu, sedangkan ayahnya lebih sering berada di luar rumah untuk bekerja [16]. Hanya sebagian anak yang diasuh oleh ayahnya, karena perceraian ataupun ibunya telah meninggal sehingga anak akan dititipkan pada neneknya atau keluarga yang lain saat ayahnya bekerja [17].

Peran orang tua dengan karakteristik pendidikan terbanyak yaitu SD, dan karakteristik pekerjaan terbanyak yaitu IRT, hal ini karena orang tua yang berpendidikan SD lebih banyak bekerja menjadi IRT sehingga orang tua lebih banyak berada di rumah untuk mendidik anaknya. Mereka banyak mendapatkan informasi terkait cuci tangan dari penyuluhan yang dilakukan Puskesmas, dan juga dari media elektronik lainnya seperti TV dan HP [18].

Hasil penelitian ini sesuai dengan penelitian Setiawan (2014) [19] bahwa peran orang tua dalam memotivasi anak untuk menncuci tangan memakai sabun rata-rata dipengaruhi karena tingkat pedidikan orang tua, maka tingkat pegetahuan orang tua dapat mempengaruhi dalam peran memotivasi anak. Selain itu pekerjaan orang tua juga mempengaruhi peran, ibu yang bekerja sebagai ibu rumah tangga maka waktu bersama anak lebih banyak sehigga orang tua mampu memperhatikan anaknya dalam menjaga kesehatan seperti halnya mencuci tangan [20].

Penelitian Evy (2021) bahwa orang tua memiliki peranan penting dalam pembiasaan mencuci tangan di masa pandemi. Orang tua tidak hanya menjadi pengingat tetapi juga 
terlibat langsung dengan cara memberikan contoh dan selalu berupaya untuk selalu mengingatkan mencuci tangan secara lisan [21].

Della (2019) menyatakan bahwa peran orang tua tentang mencuci tangan pakai sabun pada anak dipengaruhi kebiasaan mencuci tangan pada orang tua. Semakin baik peran orang tua terutama dalam keteladanan pendidikan akan pentingnya kesehatan serta menyediakan sarana dan prasarana dalam mencuci tangan dengan benar dan memakai sabun setiap sebelum dan sesudah melakukan aktivitas [22] [23].

\section{KESIMPULAN}

Berdasarkan hasil penelitian ini, peran orang tua dalam mengedukasi anak untuk mencuci tangan sebagai upaya pencegahan Covid-19 di desa Lingsar wilayah kerja Puskesmas Lingsar. Didapatkan hampir seluruh orang tua sudah berperan aktif dalam menjelaskan dan membimbing anak dalam mencuci tangan, sebagai upaya pencegahan dari penularan Covid-19 yang saat ini banyak mengancam anak-anak di Indonesia.

\section{E. UCAPAN TERIMA KASIH}

Terima kasih atas semua pihak yang telah mendukung penelitian ini.

\section{DAFTAR PUSTAKA}

[1] Nahardian, V. R, D. (2020). Fund Handwashing Sebagai Upaya Pencegahan Covid-19 Pada Anak Usia Dini. JMM (Jurnal Masyarakat Mandiri) 4 (2), 217224.

[2] Rohita. (2021). Pengenalan Covid-19 pada Anak Usia Prasekolah: Analisis pada Pelaksanaan Peran Orang Tua. Jurnal Obsesi: Jurnal Pendidikan Anak Usia Dini, Universitas Al-Azhar Jakarta Volume 5 Issue 1, 315-326.

[3] Newi, U. Z. (2019). Buku Ajar Ilmu Kesehatan (Memahami Gejala, Tanda dan Mitos). Yogyakarta: Deepublish Publisher.

[4] Rendi, A. S. N. (2020). Efektivitas Cuci Tangan Menggunakan Sabun Sebagai Upaya Pencegahan Infeksi: Tinjauan
Literatur. Jurnal Kesehatan Karya Husada (JKKH), Vol. 8 (2), 19-33.

[5] Wold Health Organization (WHO) (2020). Corona Virus Disiase (Covid-19)

[6] KEMENKES. (2020). Situs Terkini Perkembangan Corona Virus Disease-19. https://infeksiemerging.kemkes.goid/docu ment/situasi terkini-perkembangan-covid19-1-desember-2020/view

[7] Dinas Kesehatan NTB. (2020). Covid-19 NTB. https://corona.ntbprov.gp.id/

[8] Lingsar, P (2020). Update Data Harian Perkembangan Covid-19 Desa/Kelurahan Wilayah Kerja Puskesmas Lingsar Hari: Selasa Tanggal 22 Oktober.

[9] Dera R, W. E. (2018). Pengetahuan Dan Peran Orang Tua Terhadap Perilaku Hidup Bersih Dan Sehat Pada Siswa SD Di Kecamatan Kramatwatu Serang. JurnalDunia Kesmas, Volume 7, No 4, 225-232.

[10] Novrinda, N. K. (2017). Peran Orang Tua Dalam Pendidikan Anak Usia Dini Ditinjau Dari Latar Belakang Pendidikan. Jurnal Potensia, PG-PAUD FKIP UNIB, Vol. 2 No 1, 39-46.

[11] Yupi S, S. M. (2004). Buku Ajar Konsep Dasar Keperawatan Anak. Jakarta: EGC.

[12] Syahputra, M. C. (2020). Pendidikan Orang Tua Terhadap Anak dalam Menyikapi Pandemi Covid-19. Jurnal Studi Gender dan Anak, 1-110.

[13] Wang Zhou, M. (2020). Buku Panduan Pencegahan Coronavirus (101 Tips Berbasis Sains yang Dapat Menyelamatkan Hidup Anda. Wuhan, China: Association of China.

[14] Abdur R.A.S, D. (2020). Telisik Seputar Covid-19 (Pemikiran Dosen Muda IAIN Sultan Amai Gorontalo). Sumatra Barat: Insan Cendikia Mandiri.

[15] Moh. R, N. A. (2020). Perbedaan Efektivitas Hand-sanitaizer Dengan Cuci Tangan Menggunakan Sabun Sebagai Bentuk Pencegahan Covid-19. Jambura Journal Of Health Sciences and Research, vol. 2 No 2 , 65-70.

[16] Djannah, R. A. (2020). Efektifitas Cuci Tangan Menggunakan Sabun Sebagai Upaya pencegahan Infeksi: Tinjauan Literatur. Jurnal Kesehatan Karya Husada 8 (2) , 19-33. 
[17] Euis K, D. K. (2020). Analisis Peran Orang Tua dalam Mendampingi Anak di Masa Pandemi Covid-19. Jurnal Obsesi: Jurnal Pendidikan Anak Usia Dini , 241256.

[18] Alif, S. M. (2020). Peran Guru, Orang Tua, Metode dan Media Pembelajaran: Strategi KBM di Masa Pandemi Covid19. Banten: 3M Media Karya.

[19] Setiawan, I. (2014). Peran Orang Tua Dalam Memotivasi anak Mencuci Tangan Dengan Benar Dan Memakai Sabun Pada Anak Usia Pra Sekolah Di TK Aisyiyah Blimbing Kabupaten Sukoharjo. Surakarta: Sekolah Tinggi Ilmu Kesehatan Kusuma Husada Surakarta.

[20] Alif Y.Z, D. (2020). Edukasi Perilaku Hidup Bersih dan Sehat (PHBS) dalam Pencegahan Covid-19 Kepada Anak-
Anak di Panti Asuhan. Jurnal Pengabdian Magister IPA, 3 (1) , 68-76.

[21] Evy F, M. (2021). Peran Orangtua Dalam Pembiasaan Mencuci Tangan Pada Anak di Masa Pandemi Covid-19 di Kecamatan Kalideres Jakarta Barat. Jurnal Program Studi Pendidikan Anak Usia Dini, valume 13, No 2, 2301-9905.

[22] Della F, A. R. (2019). Gambaran Motivasi Dan Peran Orangtua Tentang Cuci Tangan Pakai Sabun Pada Anak Di SD Negeri 19 Kota Jambi Tahun 2019. Jurnal Akademika Baiturrahim, Vol. 8 No $2,2654-2552$.

[23] Alfitra, A. (2017). Peran Orang Tua Dengan Kepatuhan Mencuci Tangan Menggunakan Sabun Pada Anak Usia Sekolah. Jombang: Sekolah Tinggi Ilmu Keseehatan Insan Cendekia Medika. 